\title{
A copper binding site within the pathological conformer epitope of mutant SOD1
}

\author{
Ashley I. Bush* \\ Mental Health Research Institute, The University of Melbourne, Parkville, VIC, Australia \\ *Correspondence: a.bush@mhri.edu.au
}

\section{A commentary on}

Wild-type and mutant SOD1 share an aberrant conformation and a common pathogenic pathway in ALS

by Bosco, D. A., Morfini, G., Karabacak, N. M., Song, Y., Gros-Louis, F., Pasinelli, P., Goolsby, H., Fontaine, B. A., Lemay, N., McKenna-Yasek, D., Frosch, M. P., Agar, J. N., Julien, J. P., Brady, S. T., and Brown, R. H. Jr. (2010). Nat. Neurosci. 13, 1396-1403.

The etiopathogenesis of amyotrophic lateral sclerosis (ALS) remains contentious, but new findings related to mutations of the $\mathrm{Cu}, \mathrm{Zn}$-superoxide dismutase (SOD1) gene continue to provide crucial insights. Using a conformation-specific antibody that detects misfolded SOD1 (C4F6), Bosco et al. (2010) recently reported that oxidized wild-type SOD1 and mutant SOD1 share a conformational epitope that is not present in normal wild-type SOD1, but present in a subset of sporadic ALS (SALS) cases. Recombinant, oxidized wild-type SOD1 and wild-type SOD1 immunopurified from SALS tissues inhibited axonal transport in a manner similar to that of familial ALS (FALS)-linked mutant SOD1 (Bosco et al., 2010), indicating that wild-type SOD1 might develop a pathogenic modification even in SALS cases. The authors noted that a specific SOD1 residue, Cys111, was critical for the pathological C4F6 epitope (Bosco et al., 2010). This report carries added significance because it overlaps with recent observations about copper interactions in ALS pathogenesis that implicate the same residue in oxidized SOD1.

Since SOD1 is a major Cu-binding protein, and since $\mathrm{Cu}$ can be harmfully prooxidant, considerable research has explored whether aberrant $\mathrm{Cu}$ biochemistry could underlie FALS pathogenesis. Indeed, pharmacological and genetic interventions that lower intracellular $\mathrm{Cu}$ partly rescue the FALS phenotype in mutant SOD1 transgenic mice (Hottinger et al., 1997; Nagano et al., 1999, 2003; Kiaei et al., 2004; Tokuda et al., 2008). Conversely, overexpression of the $\mathrm{Cu}$-chaperone of SOD1 (CCS), which presents $\mathrm{Cu}$ to SOD1, worsens the FALS phenotype in double CCS/mutant SOD1 transgenic mice (Son et al., 2007). On the other hand, the FALS phenotype was not affected by genetic deletion of CCS (CCS knockout mice crossed with mutant SOD1 mice; Subramaniam et al., 2002). Also, active site copper was effectively eliminated from the pathogenic reaction via amino acid substitutions that disrupt copper binding but do not eliminate toxicity, and pathogenic mutant SOD1 mice express normally active and normally metallated dimeric SOD1 (Lelie et al., 2011).

The critical Cys 111 of pathogenic SOD1 described by Bosco et al. (2010) may reconcile the evidence implicating $\mathrm{Cu}$ with the evidence supporting pathogenic SOD1 instability, by supporting the possibility that ectopic binding of $\mathrm{Cu}$ outside the active site could contribute to pathogenesis (Liu et al., 2000). Immobilized Cu affinity chromatography resolves FALS-mutant SOD1 into an abnormal high-affinity fraction, termed SOD1 ${ }^{\mathrm{HAC}}$ (Watanabe et al., 2007). SOD $1^{\mathrm{HAC}}$ was observed for all pathogenic SOD1 mutants whether expressed in yeast, mammalian cell culture, or transgenic mouse spinal cords (Watanabe et al., 2007). SOD $1^{\mathrm{HAC}}$ could be generated from wild-type SOD1 by Cys111 oxidation with GSNO or hydrogen peroxide, which induced SOD1 monomerization. Covalent cross-linking of mutant SOD1 prevented such monomerization (Kishigami et al., 2010), consistent with monomerization of SOD1 being necessary for the formation of the adventitial high-affinity Cu-binding site on SOD $1^{\mathrm{HAC}}$. While the precise site is not clear, ectopic $\mathrm{Cu}$ binding to $\mathrm{SOD} 1^{\mathrm{HAC}}$ gains redox-activity. (Kishigami et al., 2010).

Mutant SOD1 is more susceptible to intramolecular disulfide reduction (Tiwari and Hayward, 2003). This renders the critical Cys111 vulnerable to modification by GSNO or peroxide that could induce monomerization and SOD $1^{\mathrm{HAC}}$ formation, consistent with the hypothesis that SOD1 is dissociated into a potentially toxic SOD $1^{\mathrm{HAC}}$ monomer when Cys111 is targeted by oxidative stress products like GSNO or $\mathrm{H}_{2} \mathrm{O}_{2}$, an event of increased likelihood in SOD1 mutants. Cys111 modification appears to disrupt the contact of the dimer interface between subunits. The finding that C111S substitution decreased SOD $1^{\mathrm{HAC}}$ in mutant SOD1 (Watanabe et al., 2007) supports this contention. A similar cysteinemediated conformational change has been reported for transthyretin, whose mutations cause familial amyloid polyneuropathy. Modification of a cysteine residue in transthyretin was shown to decrease tetramer stability, thereby generating monomer that subsequently formed amyloid (Zhang and Kelly, 2003, 2005). The findings of Bosco et al. (2010), who demonstrated that oxidation of Cys111 mediated the pathogenic properties of SOD1, would be consistent with a similar pathogenic mechanism, and explain why dimeric forms of SOD1 mutants may not be the primary toxic species (Lelie et al., 2011).

\section{REFERENCES}

Bosco, D. A., Morfini, G., Karabacak, N. M., Song, Y., Gros-Louis, F., Pasinelli, P., Goolsby, H., Fontaine, B. A., Lemay, N., McKenna-Yasek, D., Frosch, M. P., Agar, J. N., Julien, J. P., Brady, S. T., and Brown, R. H. Jr. (2010). Wild-type and mutant SOD1 share an aberrant conformation and a common pathogenic pathway in ALS. Nat. Neurosci. 13, 1396-1403.

Hottinger, A. F., Fine, E. G., Gurney, M. E., Zurn, A. D., and Aebischer, P. (1997). The copper chelator d-penicillamine delays onset of disease and extends survival in a transgenic mouse model of familial amyotrophic lateral sclerosis. Eur. J. Neurosci. 9, 1548-1551.

Kiaei, M., Bush, A. I., Morrison, B. M., Morrison, J. H., Cherny, R. A., Volitakis, I., Beal, M. F., and Gordon, J W. (2004). Genetically decreased spinal cord copper concentration prolongs life in a transgenic mouse model of amyotrophic lateral sclerosis. J. Neurosci. 24, 7945-7950.

Kishigami, H., Nagano, S., Bush, A. I., and Sakoda, S. (2010). Monomerized $\mathrm{Cu}, \mathrm{Zn}$-superoxide dismutase induces oxidative stress through aberrant $\mathrm{Cu}$ binding. Free Radic. Biol. Med. 48, 945-952. 
Lelie, H. L., Liba, A., Bourassa, M. W., Chattopadhyay, M., Chan, P. K., Gralla, E. B., Miller, L. M., Borchelt, D. R., Valentine, J. S., and Whitelegge, J. P. (2011). Copper and zinc metallation status of copper-zinc superoxide dismutase from ALS-transgenic mice. J. Biol. Chem. 286, 2795-2806.

Liu, H., Zhu, H., Eggers, D. K., Nersissian, A. M., Faull, K. F., Goto, J. J., Ai, J., Sanders-Loehr, J., Gralla, E. B., and Valentine, J.S. (2000). Copper(2+) binding to the surface residue cysteine 111 of His46Arg human copperzinc superoxide dismutase, a familial amyotrophic lateral sclerosis mutant. Biochemistry 39, 8125-8132.

Nagano, S., Fujii, Y., Yamamoto, T., Taniyama, M., Fukada, K., Yanagihara, T., and Sakoda, S. (2003). The efficacy of trientine or ascorbate alone compared to that of the combined treatment with these two agents in familial amyotrophic lateral sclerosis model mice. Exp. Neurol. 179, 176-180.

Nagano, S., Ogawa, Y., Yanagihara, T., and Sakoda, S. (1999). Benefit of a combined treatment with trientine and ascorbate in familial amyotrophic lateral sclerosis model mice. Neurosci. Lett. 265, 159-162.

Son, M., Puttaparthi, K., Kawamata,H., Rajendran, B., Boyer, P.J., Manfredi, G., andElliott, J.L. (2007). Overexpression of CCS in G93A-SOD1 mice leads to accelerated neurological deficits with severe mitochondrial pathology. Proc. Natl. Acad. Sci. U.S.A. 104, 6072-6077.

Subramaniam, J. R., Lyons, W. E., Liu, J., Bartnikas, T. B., Rothstein, J., Price, D. L., Cleveland, D. W., Gitlin, J. D., and Wong, P. C. (2002). Mutant SOD1 causes motor neuron disease independent of copper chaperone-mediated copper loading. Nat. Neurosci. 5, 301-307.

Tiwari, A., and Hayward, L. J. (2003). Familial amyotrophic lateral sclerosis mutants of copper/zinc superoxide dismutase are susceptible to disulfide reduction. J. Biol. Chem. 278, 5984-5992.

Tokuda, E., Ono, S., Ishige, K., Watanabe, S., Okawa, E., Ito, Y., and Suzuki, T. (2008). Ammonium tetrathiomolybdate delays onset, prolongs survival, and slows progression of disease in a mouse model for amyotrophic lateral sclerosis. Exp. Neurol. 213, 122-128.

Watanabe, S., Nagano, S., Duce, J., Kiaei, M., Li, Q. X., Tucker, S. M., Tiwari, A., Brown, R. H. Jr., Beal, M. F., Hayward, L. J., Culotta, V. C., Yoshihara, S., Sakoda, S., and Bush, A. I. (2007). Increased affinity for copper mediated by cysteine 111 in forms of mutant superox- ide dismutase 1 linked to amyotrophic lateral sclerosis. Free Radic. Biol. Med. 42, 1534-1542.

Zhang, Q., and Kelly, J. W. (2003). Cys10 mixed disulfides make transthyretin more amyloidogenic under mildly acidic conditions. Biochemistry 42, 8756-8761.

Zhang, Q., and Kelly, J. W. (2005). Cys-10 mixed disulfide modifications exacerbate transthyretin familial variant amyloidogenicity: a likely explanation for variable clinical expression of amyloidosis and the lack of pathology in C10S/V30M transgenic mice? Biochemistry 44, 9079-9085.

Received: 14 May 2011; accepted: 20 July 2011; published online: 11 August 2011.

Citation: Bush AI (2011) A copper binding site within the pathological conformer epitope of mutant SOD1. Front Neurosci. 5:97. doi: 10.3389/fnins.2011.00097

This article was submitted to Frontiers in Neurodegeneration, a specialty of Frontiers in Neuroscience.

Copyright $(\odot) 2011$ Bush. This is an open-access article subject to a non-exclusive license between the authors and Frontiers Media SA, which permits use, distribution and reproduction in other forums, provided the original authors and source are credited and other Frontiers conditions are complied with. 